\title{
Chapter 17 \\ Food Security, Urban Governance and Multilevel Government in Africa
}

\author{
Jaap de Visser
}

\begin{abstract}
Realising the right to food requires more than an increase in food production. Increasing access to food is equally important, so this contribution adopts a "food systems approach". Against the backdrop of a growing number of countries on the continent that are decentralising powers to cities and regions, this chapter assesses the role of local governments in South Africa with respect to food security. It argues that food security is not just a national and/or provincial government concern, but that the Constitution demands of municipalities to contribute to realising the right to food. Against the backdrop of a general introduction into the division of responsibilities between national, provincial and local government, it deploys two arguments to make this assertion. The first is located in the jurisprudence of the South African Constitutional Court on socio-economic rights. The second is located in the division of powers between national, provincial and local government. This contribution explores various linkages between a municipality's constitutional powers and food security. Specific emphasis is placed on the municipality's responsibility to regulate trade and markets as well as its responsibility to conduct spatial planning and land-use management. The argument made in this chapter is also relevant in other countries on the continent that combine socio-economic rights with multilevel government arrangements.
\end{abstract}

Keywords Food security · Local government · Provincial government · Multilevel government · Food-sensitive planning $\cdot$ Right to food $\cdot$ Spatial planning $\cdot$ Land-use management · Urban governance

\footnotetext{
The author wishes to acknowledge the National Research Foundation/Department of Science and Technology's Centre of Excellence on Food Security in South Africa. In addition, the support of Mr. Xavia Poswa, who assisted with the editing of this chapter, is gratefully acknowledged.
}

J. de Visser $(\bowtie)$

Dullah Omar Institute, University of the Western Cape, Cape Town, South Africa

e-mail: jdevisser@uwc.ac.za

R. Home (ed.), Land Issues for Urban Governance in Sub-Saharan Africa,

Local and Urban Governance, https://doi.org/10.1007/978-3-030-52504-0_17 


\subsection{Introduction}

South Africa produces enough food to feed its people, yet household food insecurity and malnutrition are unacceptably high (Oxfam 2014). It is commonly argued that addressing food insecurity is primarily the responsibility of the national and provincial governments and that local government's role is limited (Steytler 2009). Food security is typically associated with food production and thus with agriculture, and, since the Constitution allocates agriculture to the national and provincial governments, local government bears little responsibility, so the argument goes (S 44(1) \& 104(1): Constitution). This chapter argues that this is a wrong proposition for various reasons, and its argument is also relevant in other countries with constitutional arrangements similar to South Africa's.

First, food security is as much about access and quality as it is about production. South Africa's food insecurity challenge is linked to poverty and inequality, which constrains people's access to, and ability to make food choices. Most South Africans are too poor to make healthy food choices and are thus food insecure. A 2016 survey revealed that $19.9 \%$ of households had run out of money to buy food in 12 months prior to the survey (Statssa 2016), a situation not addressed by increasing production. Secondly, there are many structural and systemic problems in South Africa's food system that impedes food security. For example, the food value chain is dominated by large-scale farmers, major agri-processors and big retail stores, although diversity in the food value chain is essential for a sustainable food system (Oxfam 2014).

These two arguments may dispel the notion that food insecurity is agricultural, and therefore primarily a national and provincial issue. The right of access to sufficient food in the Constitution (S 27(1) (b)) suggests that it is a responsibility of national government, not municipalities, through increasing food production and ensuring a welfare safety net for the most vulnerable. The Constitutional Court, however, has interpreted the responsibilities of local government in other socioeconomic rights differently, holding municipalities accountable for aspects of the right to housing despite the Constitution listing housing as a power of national and provincial governments (Schedule 4 Part A). In City of Johannesburg Metropolitan Municipality v Blue Moonlight Properties 39 (Pty) Ltd and Another, the City argued it could not be held accountable for the provision of shelter to a group of residents made destitute by eviction from private land, partly because the Constitution did not allocate housing as a power to local government (Blue Moonlight: Para 50). The Court disagreed and held the city responsible for providing shelter to communities rendered homeless, emanating from the Bill of Rights (Blue Moonlight: Para 67). This has consequences for the responsibility of local government to realise the right of access to food. Just as municipalities are responsible for critical aspects of the right to housing, despite it not being a constitutional local government function, so too are they responsible for critical aspects of the right to food, despite the fact that the Constitution does not allocate "agriculture" to municipalities. Where the realisation of the right intersects with municipal responsibilities, even where assigned by 
statute, the municipality was responsible. The same should then apply to the right of access to food in section 27(1) (b) of the Constitution: municipalities are responsible for those parts of the fulfilment of the right of access to food that intersect with what is regularly done by municipalities.

To understand better this intersection between multilevel government and food security, this chapter first asks how food security intersects with the division of powers set out in the Constitution, and what points of leverage do sub-national governments, particularly municipalities, have. After tracing the constitutional division of powers between national and provincial governments in South Africa, case law reinforcing the role of municipalities in planning and management of land is explored as creating opportunities for a greater municipal role in food security matters. Finally, the relevance of South Africa's experience for the constitutions and multilevel governance in other African states is discussed.

\subsection{The Constitutional Architecture}

The Constitution relates to a federal state but with strong unitary elements, while allocating significant powers to local government. At the centre of this division of powers is a list of powers (Schedule 4A) allocated to national and provincial governments with authority to make and implement law on these matters. In case of conflict between a national and a provincial law, the Constitutional Court decides whose law prevails, using the criteria in section 146. The list of concurrent powers is extensive and includes matters such as environment, health, housing, welfare services and agriculture. This means that both national and provincial governments may regulate agriculture, a critical function related to food security, but provinces are unlikely to make agriculture laws that depart from national policy, because the criteria for national law prevailing over provincial weigh heavily towards the national government (De Visser 2017).

The Constitution also reserves some powers to provinces exclusively (Schedule $5 \mathrm{~A})$. The national government may not make law on those matters except in special circumstances (S 44 (2)). Schedule 5A includes matters such as provincial sport, provincial cultural services and veterinary services, which are hardly of fundamental importance to the state, and do not relate to food security, with two possible exceptions (abattoirs and provincial planning).

The Constitution also allocates powers exclusively to national government, any power not mentioned in Schedule 4 or Schedule 5, and includes major powers, such as the judiciary, mining and (most parts of) policing. This affects the powers around food security: land administration (i.e. rules of land tenure) is a national competency, meaning that neither provinces nor municipalities can make laws regulating farmland tenure (De Visser 2017).

The Constitution also contains specific and exclusive municipal powers subject to national and provincial minimum standards (Schedules 4B and 5B). For example, municipalities decide on rezoning and subdivision (part of "municipal planning", 
Schedule 4B) but national and provincial governments may determine minimum standards. There are many powers in the schedules that intersect with food security as will be elaborated below.

The intergovernmental financing system has a centralising effect on relations between national and provincial governments. Provinces are almost exclusively funded by the national government, raising little revenue of their own (Khumalo et al. 2011), which discourages legislative innovation by provinces, particularly when a new provincial law would require significant funding. For example, no province is likely to pass legislation with "high-cost" experimentation concerning agricultural subsidies, because it does not have a revenue model outside the structures of existing national law (De Visser 2017).

The effect of the intergovernmental fiscal system varies. Metropolitan and local municipalities have important revenue-raising powers (mainly property taxation and fees for services such as electricity, water, sanitation and sewerage), and are largely self-reliant, raising significant own revenue, complemented by intergovernmental funding in the form of the equitable share and conditional grants. Metropolitan municipalities' revenue model thus permits them to pursue distinct policy objectives, as can local municipalities with a significant urban base, but municipalities with no urban base and overwhelmingly indigent populations rely much more on intergovernmental funding (Steytler and Ayele 2018).

\subsection{Local Government Powers and Food Security}

Given the multidimensional nature of food security, many local government competencies are indirectly linked to realising the right of access to food, two in particular. Firstly, access to safe and healthy food is compromised without access to potable water, and the Constitution guarantees right of access to water (S 27(1) (b), and municipalities are responsible for water services (S 156 (1)). Municipalities are also responsible for the reticulation of electricity, essential for cooking and cold storage (S 156 (1)). The Constitution not only empowers but also instructs municipalities to provide these services. Municipalities are compelled in the Bill of Rights to ensure access to water and electricity services to all, important deal for realising the right of access to food, by extending infrastructure to communities lacking a safe and sustainable source or connection. How municipalities structure their electricity and water tariffs, (S 74 Local Government: Municipal Systems Act) is also important since food insecurity is inextricably linked to poverty.

Another intersection between food security and local government powers relates to local food trade, where the Constitution Part B lists three local government powers: trading regulations (Schedule 4), markets (Schedule 5) and street trading (Schedule 5). Municipalities may adopt and enforce trading by-laws, best understood as a power to regulate the impact of trade on the local built environment and community (Steytler and De Visser 2007). Municipalities may also regulate and operate markets (S 156 (1)), including open air markets, food markets, fresh 
produce markets, the term relating to an area, designated or managed by the municipality where stalls are set out for trading, often (but not always) limited to certain days of the week. Municipalities should realise the strategic importance of food markets in the food value chain, not to be treated as informal or the "deli" exception to the supermarket, but an indispensable part of the food value chain, improving access to healthy food, particularly for lower-income communities (Chonco 2015). Municipalities should use their regulatory competencies to influence trading practices in and around fresh produce markets, ensuring law and order, basic facilities and infrastructure, such as cold storage. The last municipal function is street trading, the operation of a small retail business in a regular public space with the permission of the municipality but not in a market, combining many similar businesses.

Municipal planning is an important local government power to plan and manage the use of land, and is distinct from the power to regulate forms of land tenure and ownership, which is a national power (Berrisford 2011). The Constitutional Court has many times determined that town planning is a municipal function, not to be interfered with by national and provincial governments (De Visser and Poswa 2019). They must limit their involvement to regulating frameworks for the effective performance by municipalities of this power, not to exercise or remove a municipality's planning powers. The 2013 Spatial Planning and Land Use Management Act (SPLUMA) codifies and regulates this division of powers.

Municipal planning has two major components under SPLUMA. The first is the power of the municipality to adopt a Municipal Spatial Development Framework (MSDF) and smaller-scale spatial development frameworks (S 5(1) (a) \& (b)). The MSDF is a spatial development vision for a municipal area, to inform future infrastructure investment and land-use decision-making (S 20 \& 21). The MSDF does not grant land-use rights, but sets policy for land-use schemes and land-use management decisions (S 22 \& 24 (1) (g)), important for a municipality's role in realising food security, connecting initiatives and public investment of government institutions across the three spheres of government. The second component is the power to determine permitted land uses in the municipality through an adopted land-use (or zoning) scheme and determining applications from landowners and developers to change zoning, amend the permitted land use, subdivide, and change land-use restrictions in title deeds and consent uses. Municipal decision-making on land-use rights is important in improving food security.

Constitution establishes municipalities in South Africa (S 151 (1)), including all agricultural land. By using its power to rezone or subdivide, a municipality may rezone agricultural land for residential, commercial or other non-agricultural purposes, which affect agricultural production and food security (Steytler 2009). Subjecting the subdivision of agricultural land to approval of the national Minister of Agriculture (S 70: SALA) gives him/her a veto power over municipal planning decisions affecting agricultural land.

The history of SALA is important. The Act was adopted long before the introduction of the current local government regime. At the time, agricultural areas were largely excluded from the boundaries of local governments and SALA was applied there to control the conversion of agricultural land. SALA survived the introduction 
of the new local government regime (Wary Holdings (Pty) Ltd V Stalwo (Pty) Ltd): 2009) and thus continues to apply and now subjects municipal planning decisions on agricultural land to a national veto.

The most important argument in its favour is that the incentive structure for municipalities fundamentally works against preserving agricultural land. The levying of property rates and the sale of municipal services (such as water, electricity, sanitation and refuse removal) are critical sources of revenue for municipalities. There is, thus, a clear incentive for municipalities to convert agricultural land into land for commercial and residential purposes and little, or no, incentive for them to retain agricultural land, so the argument goes (Steytler 2009). Secondly, it can be argued that the assessment of the agricultural potential of a piece of land requires specialised expertise. This expertise is not present in municipalities who are not geared towards regulating agriculture (which is not their function). It is present in provincial and national departments of agriculture (Steytler 2009).

One argument against SALA is that it is based on the assumption that farm size determines productivity, something on which agricultural experts disagree (Johnstone 2020). What constitutes a viable farm unit depends on matters such as soil conditions, rainfall and, most importantly, the type of agricultural model pursued on that farm. In fact, and this is the second argument against the current model, SALA was introduced and still functions to protect a powerful commercial agricultural industry, comprising of commercial farmers, the vast majority of whom are white. The Act has been singled out as a key obstacle to the transformation of the agricultural sector and the entrance of new, black agricultural entrepreneurs.

There are also legal arguments against SALA. Municipalities enjoy strong constitutional protection of their planning powers, confirmed and clarified in Constitutional Court judgments in Table 17.1. In City of Johannesburg Metropolitan Municipality v Gauteng Development Tribunal 2010 (9) BCLR 859 (CC), the City of Johannesburg asked the Constitutional Court to declare parts of the Development Facilitation Act (DFA) unconstitutional. The DFA empowered provincial planning tribunals to take land-use decisions, something that the Constitution reserves for municipalities, so the city argued. The Constitutional Court agreed with the city and declared parts of the DFA unconstitutional. This essentially located municipalities at the centre of the land-use management framework. In subsequent years, more constitutional litigation on this followed. Without fail, each judgement confirmed the approach taken in Gauteng Development Tribunal, namely, that national and provincial governments may not usurp the powers of municipalities with respect to "municipal planning". The national government does not trump municipal land-use decisions by issuing mining licences (Maccsands). Provincial governments may not subject municipal land-use decisions to a veto, even if the development impacts on an entire region (Lagoonbay). Provincial governments may also not subject municipal land-use decisions or building approvals to provincial or national appeals (Habitat Council, Pieterse, Tronox and Chairman of the National Building Regulations Appeal Board). Five key judgments are summarised below, and, given that firm jurisprudential trend, SALA might not survive a constitutional challenge to its ministerial veto powers over municipal land-use management decisions. 
Table 17.1 Constitutional Court judgments on municipal planning and building regulations

\begin{tabular}{l|l|l|l|l|l}
\hline Judgement & $\begin{array}{l}\text { Gauteng } \\
\text { Development } \\
\text { Tribunal } \\
(2010)\end{array}$ & $\begin{array}{l}\text { Maccsands } \\
(2012)\end{array}$ & $\begin{array}{l}\text { Lagoonbay } \\
(2013)\end{array}$ & $\begin{array}{l}\text { Habitat Council } \\
(2014) / \text { Pieterse } \\
\text { (2016)/Chairman } \\
\text { National Building } \\
\text { Regs Council } \\
(2018)\end{array}$ & $\begin{array}{l}\text { Tronox } \\
(2015)\end{array}$ \\
\hline $\begin{array}{l}\text { Key } \\
\text { question }\end{array}$ & $\begin{array}{l}\text { Can province } \\
\text { take "town } \\
\text { planning" } \\
\text { decisions? }\end{array}$ & $\begin{array}{l}\text { Does having a } \\
\text { national } \\
\text { mining } \\
\text { licence make } \\
\text { municipal } \\
\text { land-use } \\
\text { approval } \\
\text { unnecessary? }\end{array}$ & $\begin{array}{l}\text { Can province } \\
\text { overrule a } \\
\text { municipality } \\
\text { when the } \\
\text { impact of the } \\
\text { development } \\
\text { straddles the } \\
\text { municipal } \\
\text { boundary? }\end{array}$ & $\begin{array}{l}\text { Can a provincial } \\
\text { or national body } \\
\text { be the appeal } \\
\text { authority for } \\
\text { municipal } \\
\text { planning or } \\
\text { building } \\
\text { regulations } \\
\text { decisions? }\end{array}$ & $\begin{array}{l}\text { What if the } \\
\text { provincial } \\
\text { appeal board } \\
\text { is an } \\
\text { independent } \\
\text { expert body? }\end{array}$ \\
\hline $\begin{array}{l}\text { ConCourt's } \\
\text { answer }\end{array}$ & $\begin{array}{l}\text { No, the } \\
\text { municipality } \\
\text { takes town } \\
\text { planning } \\
\text { decisions } \\
\text { (rezoning and } \\
\text { township } \\
\text { development }\end{array}$ & $\begin{array}{l}\text { No, the } \\
\text { municipality } \\
\text { must still take } \\
\text { its own } \\
\text { decisions }\end{array}$ & $\begin{array}{l}\text { No, the } \\
\text { municipality } \\
\text { must still take } \\
\text { its own } \\
\text { decisions }\end{array}$ & $\begin{array}{l}\text { No, an appeal } \\
\text { from a } \\
\text { municipality to a } \\
\text { provincial or } \\
\text { national body is } \\
\text { not constitutional }\end{array}$ & $\begin{array}{l}\text { No, } \\
\text { (confirming } \\
\text { Habitat } \\
\text { Council) }\end{array}$ \\
\hline
\end{tabular}

Source: author

The policy and constitutional flaws of SALA should not be read to imply that municipal power to change the permitted use of agricultural land must be unfettered. The challenges surrounding the orientation of municipalities towards development and the capacity lacuna in local government on agriculture are very real and serious. However, the current regime must be replaced by a more refined regime. SPLUMA, the new legislative regime for municipal planning, is an important start to that. It regulates how municipalities must conduct their spatial planning and landuse management. There are at least eight specific provisions in SPLUMA that relate to the agricultural potential of land under consideration for rezoning or subdivision:

1. The Preamble to the Act specifically mentions the right to food as one of the drivers for the adoption and implementation of SPLUMA.

2. Section 3(d) of SPLUMA includes "the sustainable and efficient use of land" as one of its objects.

3. Section 7(b)(ii) of SPLUMA instructs municipalities to "ensure that special consideration is given to the protection of prime and agricultural land".

4. Section 8(2) of the Act empowers the national Minister to proclaim norms and standards on matters such as "desirable settlement patterns", "rural revitalisation" and "sustainable development".

5. Section 12(1)(n) of the Act stipulates that spatial development frameworks must "give effect to (...) the sustainable utilisation and protection of agricultural land". 
6. Section 21(j) of the Act specifies this for municipalities and insists that the MSDF must include "a strategic assessment of the environmental pressures and opportunities within the municipal area, including ... high potential agricultural land".

7. Section 25(1) of the Act demands that municipal land-use schemes must have "minimal impact on ... natural resources".

8. Section 52 (1) of the Act empowers the national Minister to decide land development applications "where such an application materially impacts on (...) food security (...) or land use for agriculture". While this provision may sound similar to what is provided in SALA, it differs in two important respects. Firstly, while SALA provides for a veto on a municipal decision, SPLUMA provides for a procedure alongside the municipal procedure and resulting in a separate decision. Secondly, while SALA locates the veto power in the Minister responsible for agriculture, SPLUMA locates this national power in the Minister of Rural Development and Land Reform.

Proponents of SALA may argue that the above do not provide equivalent protection as the ministerial veto, but they do protect agricultural resources against harmful development less restrictively than the ministerial veto. The powers under section 52 , in particular, empower the national government to stop development that may harm food security, ultimately with the same effect as the SALA veto.

As well as impacting the availability or production of healthy food, municipal planning powers also affect the municipality's ability to facilitate access, particularly for disadvantaged communities. Take, for example, a municipality's power over zoning, i.e. the adoption of a land-use (or zoning) scheme and the alteration of existing zonings. (S 24, 28 \& 41: SPLUMA). Much of South Africa's formal planning landscape for suburbs is characterised by "single-use zones", i.e. the separation of residential, commercial, industrial and other uses. Commercial activity is generally discouraged in residential areas. While this approach serves a peaceful suburban lifestyle, separate from the hustle and bustle of commercial areas, it makes little sense in South Africa's low-income and informal areas where residential and informal business activity flows into one another. Residential dwellings are used for commercial use, and it is not uncommon for informal retailers to reside in the places from which they trade. In that context, the dogged insistence on single-use zones as the norm, constricts and imposes a heavy regulatory burden on informal entrepreneurial activity. Deviation from the single-use zoning norm necessitates applications for departures, consent uses, rezoning and building permits and thus entails (oftentimes expensive) bureaucracy. Ultimately, it pushes small, informal businesses into illegality (Sustainable Livelihoods Foundation 2017). SPLUMA now expects municipalities to extend land-use schemes (or zoning schemes) into informal areas (S 24 (1): SPLUMA). However, it also instructs them to do so sensibly and incrementally, i.e. with due consideration of effects such as the above (S 24 (2): SPLUMA). For example, section 24(2)(c) of SPLUMA instructs municipalities to "include provisions that permit the incremental introduction of land use management and regulation in areas under traditional leadership, rural areas, informal 
settlements, slums and areas not previously subject to a land use scheme". Furthermore, SPLUMA envisages the adoption of municipal planning by-laws that deal with the enforcement of land-use schemes (De Visser and Poswa 2019).

The Constitutional Court has accepted that asymmetrical enforcement of municipal rules, such as municipal tariffs, is permissible if there is an underlying, rational policy that is formally expressed (City Council of Pretoria V Walker 1998). It can be argued that the extension of zoning rules into low-income and informal areas can be accompanied by low-intensity enforcement of those zoning rules in order not to chase microenterprises into illegality (De Visser and Poswa 2019). Small, informal food outlets play a critical role in local food system (Johnstone 2020). It follows, therefore that a municipality's efforts to use its zoning powers to regularise (or not) microenterprises matters a great deal for local food systems.

Furthermore, the municipality can influence the regulatory and bureaucratic burden that is imposed on informal food traders in low-income and informal settlements. SPLUMA recognises the bureaucratic burden that the planning system imposes. It instructs municipalities to identify areas in its MSDF "where incremental approaches to development and regulation will be applicable" and where "shortened land use development procedures may be applicable and land use schemes may be so amended" (S 21 (k) \& (i) (ii): SPLUMA). It is argued that municipalities should consider finding ways to ease the regulatory burden on informal food traders in low-income and informal settlements. This may relate also to the setting of tariffs for land-use applications: the municipality now controls the tariff structure and could consider adopting a progressive tariff structure that encourages informal traders to regularise their building and planning approval. In short, a progressive approach by the municipality to the regulatory burden surrounding planning and building regulations could enable more informal traders to formalise the planning approvals pertaining to their businesses. This adds stability to their operations and increases their chances of accessing capital and overall benefits for the accessibility of healthy food particularly in disadvantaged areas.

A third example of a point of leverage for a municipality that may be used to facilitate greater access to healthy food relates to the use of conditions to land-use approvals. A municipality that is considering a land-use application, such as an application for rezoning, subdivision, consent use, etc., has leverage over the applicant. Section 43(1) of SPLUMA provides that an application may be approved subject to such conditions as the municipality prescribes. This leverage can, and should, be used by the municipality to negotiate outcomes that go beyond the narrow interests of the applicant in a land-use right. This already happens. It is common for municipalities to impose condition that assist it to recoup the additional bulk expenditure (e.g. a new sewerage plant) required to make the development possible. More progressively, cities are starting to approve inner city commercial housing projects together with conditions that force developers to include low-cost housing units into the development (Ndifuna Ukwazi 2018). It is argued that municipalities should explore using this leverage to impose conditions that force developers into the behaviour that improves the food system, such as facilitating market access for small and informal traders. For example, why not add a condition to the approval of 
a retail mall development that a certain percentage of the floor space is designated for small, emerging food retailers?

\subsection{Relevance Elsewhere}

How far are these arguments relevant for countries elsewhere on the continent? An increasing number of constitutions list sub-national powers, whether federations, such as Ethiopia and Nigeria or "semi-federations" such as Kenya. Others are countries setting out the powers of local government in their Constitutions include Uganda, Tunisia and Zambia. The arguments in this chapter interpreting subnational powers, such as those related to planning, trade and markets, to link to food security could find resonance in those countries. Constitutions with enforceable socio-economic rights are scarcer, although countries such as Uganda and Nigeria list them as duties on the state but not as rights enforceable in court. Kenya is an exception, with a Constitution containing justiciable economic and social rights and devolution of powers to counties. Article 43 contains rights pertaining to healthcare, housing, sanitation, food, water, social security and education, and enforcement of these rights by the Kenyan courts will doubtless affect the devolution of functions and powers (De Visser 2015).

\subsection{Conclusion}

This chapter has argued that the duty to realise the right of access to food in South Africa is not exclusively to national and provincial governments, but many functions allocated to local government allow municipalities to make meaningful contributions on the right of access to food. Certain planning responsibilities ultimately impact food production and can improve the availability of food. The legal framework for controlling development of agricultural land is no longer appropriate, and a new approach should move away from focus on farm size as a proxy for productivity, to recognise the enhanced status of local government in the regulation and control of land use. Municipal planning responsibilities are equally important to better balance the role of large retailers and local food traders in the market. They can reduce the regulatory burden on food traders in low-income and informal settlements. Other municipal competencies that can improve access to healthy and nutritious food include regulating fresh produce markets to connect small-scale farmers and informal traders to consumers.

This chapter does not claim that the above suggestions as policy proposals and policy experts may disagree or have other proposals but argues rather that local government powers allow intervention to improve the right of access to food, which can benefit all South Africans. Returning to the original research question, there are many points where local government powers intersect with what is required to 
realise the right of access to food. If municipalities use this leverage constructively and progressively, more progress can be made in the quest to ensure access to food.

\section{References}

Berrisford S (2011) Unravelling apartheid spatial planning legislation in South Africa - a case study. Urban Forum 22:247-263

Chonco T (2015) An analysis of municipal regulation and management of markets as an instrument to facilitate access to food and enhance food security LLM Thesis, University of the Western Cape

Constitution of the Republic of South Africa

De Visser J (2017) Concurrent powers in South Africa. In Steytler N (ed) Concurrent powers in federal systems. Brill Nijhoff, Leiden

De Visser J (2015) Enforcement of socio-economic rights against local governments in South Africa. In: Bosire C, Gikonyo W (eds) Animating devolution in Kenya Rome: IDLO 193-28. Available at http://bit.ly/1KqDmpo

De Visser J, Poswa X (2019) Municipal law making under SPLUMA: a survey of fifteen "first generation" municipal planning by-Laws. Potchefstroom Electronic Law Journal Vol 22

Johnstone S (2020) The role of local government in a food systems approach. PhD Thesis, University of the Western Cape

Khumalo B, Dawood G, Mahabir J (2011) South Africa's intergovernmental fiscal relations system. In: Steytler N, Ghai Y (eds) Kenyan-South African dialogue on devolution. Juta, Cape Town

Local Government: Municipal Systems Act 32 of 2000

Ndifuna Ukwazi (2018) Cape Town planning tribunal imposes first-ever affordable housing condition on zero2one skyscraper. https://www.facebook.com/NdifunaUkwazi/posts/cape-townplanning-tribunal-imposes-first-ever-affordable-housing-condition-on-z/1784109608274285/. Accessed 26 Nov 2018

Oxfam GB (2014) Hidden hunger in southern Africa: the faces of hunger and malnutrition in a food-secure nation

Statistics South Africa (2016) Statistical release: community survey. Available at www.statssa.gov. za/?page_id=737\&id=1. Accessed 24 June 2018

Steytler N (2009) The decisions in Wary Holdings (Pty) Ltd V Stalwo (Pty) Ltd and Another 2009 (1) Sa 337 (Cc): be wary of these holdings. Constitutional Court Review 2009 (2)

Steytler N, Ayele Z (2018) Local governments in African federal and devolved systems of government: the struggle for a balance between financial and fiscal autonomy and discipline. In: Valdesalici A, Palermo F (eds) Comparing fiscal federalism. Brill Nijhoff, Leiden

Steytler N, De Visser J (2007) Local government law of South Africa. LexisNexis, Durban

Subdivision of Agricultural Land Act 70 of 1970

Subdivision of Agricultural Land Repeal Act, 1998

Sustainable Livelihoods Foundation Post-apartheid spatial inequality: obstacles of land use management on township micro-enterprise formalisation (2017)

\section{Case Law}

City Council of Pretoria v Walker 1998 (3) BCLR 257 (CC)

City of Johannesburg Metropolitan Municipality v Gauteng Development Tribunal and others [2008] 2 All SA $298(\mathrm{~W})$ 
City of Johannesburg Metropolitan Municipality v Blue Moonlight Properties 39 (Pty) Ltd and Another 2012 (2) BCLR 150 (CC) (Blue Moonlight)

City of Johannesburg Metropolitan Municipality v Chairman of the National Building Regulations Review Board and Others 2018 (8) BCLR 881 (CC); 2018 (5) SA 1 (CC)

Habitat Council and Another v Provincial Minister of Local Government, Environmental Affairs and Development Planning, Western Cape and Others [2013] ZAWCHC 112 (14 August 2013)

Lagoonbay Lifestyle Estate (Pty) Ltd v The Minister for Local Government, Environmental Affairs and Development Planning of the Western Cape \& Others [2013] ZASCA 13 (15 March 2013)

Maccsand (Pty) Ltd v City of Cape Town and Others 2012 (4) SA 181 (CC)

Pieterse NO v Lephalale Local Municipality 2017 (2) BCLR 233 (CC)

Tronox KZN Sands (Pty) Ltd v KwaZulu-Natal Planning and Development Appeal Tribunal and Others 2016 (3) SA 160 (CC)

Wary Holdings (Pty) Ltd v Stalwo (Pty) Ltd 2008 (11) BCLR 1123 (CC) 